\title{
1
}

\section{Australia, the Asia-Pacific and the social sciences}

\section{Vera Mackie, Carol Johnson and Tessa Morris-Suzuki}

In 2013, Australia's Abbott Liberal government announced a 'New Colombo Plan', which supports Australian undergraduates to visit selected Asian countries to study, research or undertake internships, mentorships and practicums. One year earlier, the Gillard Labor government had released a White Paper, Australia in the Asian Century, which emphasised the importance of developing an education system that encourages Australians to be 'Asia-literate' and 'Asia-capable'. The White Paper stressed the importance of strengthening 'research and teaching links between Australian institutions and those in the region' (Commonwealth of Australia 2012: 16-17; Department of Foreign Affairs and Trade n.d.).

In this volume, we argue that in the twenty-first century not only will the study of Asian societies and languages be important but also the study of the diverse forms of knowledge produced outside the Euro-American centres. These diverse forms of social science knowledge, coming from differing intellectual traditions, can make important methodological and theoretical contributions as well as filling empirical gaps. They will be relevant not just for those who study Asian societies but also for those who study a range of societies grappling with similar problems, including Australia. To understand why such a fundamental intellectual engagement is so important, it is necessary 
to understand both the historical background to the development of the social sciences in Australia and the changing geopolitics of knowledge in which the contemporary social sciences are situated.

We therefore begin by outlining the historical origins of, and intellectual influences that helped to shape, the social sciences in Australia. We will outline the impact of those origins and influences on Australian social scientists' study of the region and argue for the need to develop more contemporary approaches, especially a deeper and more reciprocal intellectual engagement, in the conditions of the twenty-first century.

\section{Modes of engagement}

By juxtaposing the New Colombo Plan of the twenty-first century with the original Colombo Plan of the 1950s, we can gain insight into the changing relationships between Australia and its neighbours since the mid-twentieth century and the changing conceptions of intellectual engagement that have resulted.

The original Colombo Plan was established in 1950, at a Commonwealth Conference of Foreign Ministers, and provided infrastructure and skills development to scholars from developing countries. The original members were Australia, Britain, Canada, Ceylon, India, New Zealand and Pakistan. There are currently 26 member nations, no longer restricted to the British Commonwealth. In Australia, the Colombo Plan is firmly lodged in national cultural memory, as it brought international students from a range of developing nations to study at Australian universities over several decades (Indelicato 2015: 1-16; Kartomi 2013: 240-57; Oakman 2004), and helped forge relationships with individuals who would often go on to be leaders in their own countries. Tens of thousands of students studied in Australia under this scheme, and many more Australians came into contact with these students in classrooms, dormitories, student union activities and the homes of host families (Downer 2005; Lowe 2014).

In the 1950s, when the original Colombo Plan was established, Australia was firmly aligned with the Anglophone powers: the United States and the United Kingdom. Australia had been founded on the basis of a series of British colonies from the mid-eighteenth century, but by the mid-twentieth century it had taken on a similar colonial role in the Asia-Pacific region as the administrator of territories such as Papua New Guinea. As a relatively wealthy nation, Australia also provided scholarships and other forms of development aid to the countries of the region. Between the 1950s and the 1970s, Australia gradually dismantled the White Australia Policy, repealing the Immigration Restriction 
Act and moving to an official policy of multiculturalism. By the 1990s, hosting international students was no longer a matter of benevolence, but rather a major 'export' industry, with international students' tuition fees and their purchases of other goods and services providing a major boost to the Australian economy. Although Australia still provides a small number of international student scholarships through AusAID and individual university scholarship schemes, the majority of our international students are fee-paying. The RuddGillard Labor governments introduced the Endeavour Fellowships, a two-way scheme that allowed Australians to travel overseas, and brought scholars from neighbouring countries to Australia (Australian Education International n.d.). This was in the spirit of the government's White Paper, Australia in the Asian Century, which had a vision of a reciprocal relationship between Australia and other countries in the region, and demonstrated a recognition that learning could be a multidimensional and multidirectional process (Commonwealth of Australia 2012). By contrast, the New Colombo Plan funds only Australians to travel overseas, 'complementing the thousands of students from the region coming to Australia to study each year' (DFAT n.d.).

This snapshot of different forms of engagement through the participation of young people in higher education provides an introduction to the concerns of this book. While there are diverse elements to the relationship between Australia and the Asia-Pacific region-economic, political, diplomatic, military, strategic, cultural and interpersonal — we are particularly interested in exploring the role of academic social scientists. This volume grew out of an annual symposium of the Academy of Social Sciences in Australia, which focused on 'Australian Social Sciences in the Asian Century'. ${ }^{1}$ As with the example of international education described above, we argue that there can be several different models of social scientific engagement with the region.

In the past, we can identify a colonialist view that saw Anglophone societies as producers and dispensers of knowledge, primarily engaged in describing 'other' societies and engaging with 'other' societies in a pedagogical manner. Australia's own Indigenous peoples were also the objects of academic knowledge. In this sense, Australia can be seen as inheriting Euro-American social scientific traditions. Australia's first universities were established in the mid-nineteenth century, in the separate colonies that would come together under Federation in 1901. They were modelled on the British universities of the time, and there was a period of expansion of the university sector in the early post-World War II period, which closely paralleled developments in the United Kingdom (Connell 2007; Connell in this volume; Patel in this volume).

1 For information about the 2012 Annual Symposium of the Academy of the Social Sciences in Australia (convened by Carol Johnson and Vera Mackie), see www.assa.edu.au/events/symposium/2012. Consulted 7 October 2013. 
With respect to the study of societies in the Asia-Pacific region, from the mid to late twentieth century, we can identify an instrumentalist model in which knowledge of 'other' societies is primarily for the purposes of advancing Australian economic interests. Much of the late twentieth-century interest in Asian languages and studies focused on economic and strategic reasons for studying the societies and cultures of Indonesia, Japan, China and (South) Korea (COAG 1994; NALSAS 1998). ${ }^{2}$ In this volume, however, we will propose a dialogical model whereby societies in the region are engaged in the common pursuit of solutions to regional problems, and the flows of knowledge necessarily move in multiple directions.

To consider the role of the social sciences in Australia's engagement with the Asia-Pacific region, we need some historical background and context. We need to survey Australia's engagement with the Asia-Pacific region, describe Australia's inheritance of a particular Euro-American view of the social sciences, acknowledge recent paradigms that challenge Eurocentric models, situate the social sciences in the age of globalisation, and consider what this means for practising the social sciences in the twenty-first century.

\section{Engaging with the Asia-Pacific region}

David Walker and Agnieska Sobocinska point out that every Australian generation seems to rediscover Asia, all the time imagining that theirs is the first to be conscious of the changing economics and geopolitics of the region. They quote Australian prime minister Andrew Fisher, who commented in 1915 that the 'rise' of Japan had 'no parallel in our history', and journalist George Johnston, who at mid-century thought we stood 'at the very beginning of another great cycle of civilisation', which, one day, would 'push the centre of gravity of civilisation back to the Orient' (Walker and Sobocinska 2012: 3).

As several commentators have noted, Australia's relationship with the region has often been associated with ambivalence and anxiety (d'Cruz and Steele 2003; Walker 1999; Walker and Sobocinska 2012: 1-23). The first Japanese language program in Australia was established at the University of Sydney in 1917, perhaps in response to anxiety about Japan's increased role in the region. Just two years later, in 1919, the Australian government succeeded in opposing Japan's proposal for a 'racial equality' clause in the founding charter of the League of Nations after World War I (Shimazu 1998). Although there was some development of trading relationships with Japan in particular in the early twentieth century, this was cut short in the 1930s as Japan withdrew from

2 Some plans also included Thailand, Vietnam and India. 
the League of Nations in the wake of criticism of its invasion of Manchuria, culminating in trade embargoes against Japan in the mid-1930s (Jones 2001: 133-62).

After the bombing of Pearl Harbor in 1941 and the fall of Singapore in 1942, the Asia-Pacific region was the site of warfare between the Allies and Japan. As Prue Torney-Parlicki points out, for many in mid-century Australia, the dispatches of war correspondents were a major source of their knowledge about the region (Torney-Parlicki 2000). For a generation of Australian men, their contact with the Asia-Pacific region was as combatants in World War II, as occupiers of the defeated Japan from 1945 to 1952, or as combatants in the Korean and Vietnam wars. Women, too, supported these military actions: as nurses, as members of the women's services or in other ways. Meanwhile, on the home front, opposition to the Vietnam War was the focus of civil society activity from the 1960s. In 1965, MP Jim Cairns argued that Australians needed to know more about Asia, proposing a relationship based on pacifism rather than militarism:

The most significant recent change in the outlook of Australians is their growing awareness of Asia. We are all aware of Asia. Many of us are afraid of it. Few of us understand it (Cairns 1965: 1).

Asia has been constructed in Australian political discourse as a source of both fear and hope (Johnson et al. 2010: 59-79). There is also a long history of Australian governments pursuing policies that emphasise the importance of trading with Asia (McFadyen 1949; on the 1930s, see Jones 2001: 133-62). By the late twentieth century, Australian governments were becoming more aware that the international economy would be transformed by the economic development of countries in the Asian region. One consequence was that intellectual aspects of the engagement with Asia began to be taken more seriously, even if the impetus for such engagement was largely economic. In 1988, then prime minister Bob Hawke made a speech at the conference of the Asian Studies Association of Australia on the importance of studying Asian languages. This speech was widely credited with contributing to that year's massive rise in Asian-language enrolments at universities. This was congruent with the Hawke-Keating governments' embrace of the Asia-Pacific Economic Cooperation (APEC) concept, starting with Hawke's speech in Seoul in 1989 (APEC n.d.). Former prime minister Paul Keating (1992) argued that Australians needed to improve their cultural and language skills to engage with Asia, and that we needed to draw on the skills of Australia's multicultural population.

By the twenty-first century, prime minister Kevin Rudd (2008) went even further, arguing that China and India were 'looming to dominate the 21 st Century, just as the United States and the United Kingdom had dominated the 20th'. Drawing on knowledge gained as a student of Asian studies at The Australian National 
University, Rudd (2009) emphasised the important intellectual contributions of countries such as India and China, both historically and in the contemporary period. Foreign minister Stephen Smith argued that ' $[\mathrm{w}] \mathrm{e}$ have to make Australia's understanding of Asian literacy and Asian culture almost second nature to us' (The Advertiser 21 April 2008).

We have had several iterations of government interest in policies on teaching Asian languages and studies. There has also been a long history of lobbying on behalf of Asian languages and studies. ${ }^{3}$ The Commonwealth government's (2012) White Paper on Australia in the Asian Century, however, provided fresh context for questions about practising the social sciences in the twenty-first century.

The Australia in the Asian Century White Paper was different from earlier such reports in taking a 'whole of government' approach, with the Gillard government appointing a minister to have explicit responsibility for policies related to the 'Asian Century'. There is some continuity, however, in its focus on instrumentalist reasons for engaging with the region: economic relationships; the fact that our major trading partners come from the Asia-Pacific region; and the fact that there is a growing middle-class market for consumer goods, tourism and educational services in the region. Several contributors to this volume comment on the Asian Century White Paper from diverse points of view, as we shall see below.

The Abbott government did not always give the concept of the Asian Century the kind of emphasis given by the Rudd and Gillard governments. Indeed, when she was shadow minister for foreign affairs, Julie Bishop (2013a) suggested that while the term 'Asian Century' had currency, the 'Global Century' might be an even better term, given 'the rise of different powers challenging the established powers'. Nonetheless, then Prime Minister Tony Abbott (2014) acknowledged that 'with a combined population of 1.5 billion and a GDP of \$15 trillion, China, Japan, and Korea collectively have decisively shifted the world's centre of economic gravity'. He argued that we are no longer 'at the wrong end of the world but the right one', and expressed his confidence that 'the Asian Century will be Australia's moment too' (Abbott 2014). Significantly, Abbott's successor as Prime Minister, Malcolm Turnbull (2015), has stressed the importance of 'the great geopolitical transformation of our time - the economic rise of emerging Asia'. Bishop (2013c) has focused on the importance of 'economic diplomacy' in engaging with Australia's region, given the increasing economic importance of the Indian Ocean and Asia-Pacific regions. Bishop (2013b) has also emphasised the importance of engaging intellectually with Asia, noting the importance of

3 See Auchmuty (1971); Asian Studies Association of Australia (2002); Asian Studies Council (1988, 1989); COAG (1994); FitzGerald (1980); Kersten et al. (1996); NALSAS (1998). 
top-ranked universities in the region. ${ }^{4}$ Under the New Colombo Plan, young Australians are encouraged not only to learn Asian languages but also to engage in study exchanges as a significant form of regional engagement (Bishop 2013b; 2013c: 4). Indeed, the new scheme is described as being 'designed to be a rite of passage for young Australians' and intended to ensure that it is 'the norm for young Australians to spend time living in the region' (Bishop 2013c: 12).

Recent statements on the New Colombo Plan focus on the 'Indo-Pacific', covering an area from the Indian Ocean to the Pacific (DFAT n.d.). In other words, this refers to a region that encompasses South Asia, Southeast Asia, East Asia and the Pacific. Indeed, the revival of the place name 'Colombo' might also suggest a (re)orientation towards South Asia. These changes in the terminology to describe Australia's neighbourhood underline the fact that 'the Orient', 'Asia', the 'Asia-Pacific' and the 'Indo-Pacific' are all constructed categories. The different nuances and connotations of each term reflect shifting geopolitics, different ways of imagining Australia's place in the world, and changing views of which countries are important to Australia. ${ }^{5}$ In this introductory essay, we sometimes refer in different places to 'Asia', the 'Asia-Pacific' or the 'IndoPacific', depending on the particular period we are writing about. Chapters variously focus on particular countries, ranging from Pakistan, India, China and Japan down to the Philippines and Indonesia, with Australia included as part of the broader Asia-Pacific region. We are also, however, keenly interested in the interconnections between these places, and recognise that the Australian population includes a significant proportion of nationals and residents of Asian heritage (Martin et al. 2015). Now let us turn to a brief consideration of the historical role of the social sciences in contributing to Australia's engagement with the region.

\section{Social sciences, area studies and beyond}

Australia's first universities were established in the mid-nineteenth century, in the capitals of the separate colonies. The late nineteenth-century universities in Australia provided a combination of liberal arts and fields of study with some vocational or practical application-law, medicine, engineering, economics. These universities were established with a professoriate drawn from British

\footnotetext{
4 One of the most influential university ranking systems, the Academic Ranking of World Universities (ARWU)/'Shanghai Jioatong', is based in China.

5 On the instability of the category 'Asia', see, inter alia, Spivak (2008); on the 'Asia-Pacific', see Wilson and Dirlik (1995). Many thinkers in diverse countries in the region commonly described as Asia have also, of course, resisted this homogenising label (Wang 2007; Hall 2009). It should also be noted that while the term 'Asian Century' has gained currency in Australia, elsewhere the twenty-first century has been referred to as the 'Pacific Century' (Nguyen and Hoskins 2014).
} 
universities, with some appointments from the United States and a few homegrown academics who were likely to have completed higher degrees overseas (Dale 2012). At the end of World War II, there were six universities in Australia (the Universities of Sydney, Melbourne, Adelaide, Tasmania, Queensland and Western Australia), with 16,000 students. The Australian National University was established in 1946. The tertiary education system expanded in the 1950s and the 1960s. There were nine universities with a total of 31,000 university students in 1955, and 14 universities with 81,000 students in 1965. The university system underwent further expansion in the late 1980s when the older universities were amalgamated with former teachers' colleges, technical colleges and colleges of advanced education, bringing total enrolments to 420,000. By 1996 there was a total of 630,000 university students in Australia (Macintyre 2010: 22-5). In 2014 there were about one million university students in the country (Universities Australia 2014). Each period of growth also saw changing configurations of the international student population. About 20,000 students came from mainly Asian countries in the period of the Colombo Plan, with a similar number of private overseas students. There was growth in the full-fee-paying international student population from the 1980s. By 2011, one in five students at Australian universities were international students (Martin et al. 2015).

The social sciences originally grew out of Enlightenment rationalism in Europe in the eighteenth century. They are 'a product of modernity, their point of departure the emergence of society as a separate and autonomous realm of human activity' (Macintyre 2010: 4). They were established as separate disciplinary areas of study in universities in the United States in the late nineteenth century. Australia was slower to establish similar programs. Sociology had a difficult beginning in Australia, with short-lived attempts to establish sociology programs in the 1920s, although training in social work was established by the mid-1930s (Miller and Nicholls 2014: 21-33). The first chair in anthropology was established in 1926, and anthropology programs were seen to be highly relevant to Australia's involvement in the policing and administration of the territory of Papua New Guinea (Macintyre 2010: 18).

Australia was thus in an ambivalent position. In the late nineteenth and early twentieth centuries, Australia was seen as a 'social laboratory', with its universal suffrage, pioneering Labor governments, wage arbitration systems, noncontributory old-age pensions and strong union movements. At the same time, it was a former colony of the United Kingdom, nominally independent after 1901, but still beholden to the British Privy Council and the British monarchy (through the Governor-General and state governors). Australia was a colonialsettler society that asserted its difference from other British colonies like India 
and Malaya through the White Australia Policy. Australia's Indigenous peoples were the focus of Euro-American anthropological research, as were the peoples of Papua New Guinea and the Pacific (Wolfe 1999).

The social sciences were important in both wartime Australia and the early post-World War II reconstruction period. As far as Asian studies is concerned, Japanese-language training was vital for military intelligence during World War II, for the conduct of war crimes trials at the end of the war and in the Allied occupation of Japan from 1945 to 1952. Some of these military specialists went on to teach in universities. The Australian Defence Force continues to teach Asian languages at the Australian Defence Force Language School near Melbourne, and Asian studies is part of the curriculum at the Australian Defence Force Academy in Canberra (Department of Defence 2000).

In the United States, the study of societies outside the Euro-American centres in the post-World War II period was brought together under the rubric of 'area studies'. That is, these fields of study were defined by a geographical focus rather than a disciplinary focus. Area studies had its roots in World War II and the subsequent establishment of the Cold War world view. Area studies teaching and research were closely aligned with US defence and foreign policies.

There have been spirited debates around area studies, modernisation theory and the social sciences in North America. The Bulletin of Concerned Asian Scholars (now known as Critical Asian Studies) was established in 1968 by academics concerned about the direction of US foreign policy in Asia, particularly the military conflict in Vietnam (Committee of Concerned Asian Scholars 1968), in which Australia was also involved. As early as 1975, John Dower, in his essay on modernisation theory, pointed out that area studies in the United States had been implicated in US government foreign policy objectives (1975: 3-108).

A generation of scholars of Asia has been influenced by Edward Said's book Orientalism, in which he argued that Orientalism is a Western style for 'dominating, restructuring, and having authority over the Orient' (1978: 3). While Said's book largely focused on European representations of the Middle East, conceptions of the 'Orient' also included Asian countries, as has been pointed out before and after Said's book (Breckenridge and van de Veer 1993: 3-4). In any case, the term Orientalism has been adapted to a range of situations where scholars and their objects of study are embedded in structured relationships of inequality. What is important about Said's intervention is not so much whether he was writing about the Middle East, South Asia or East Asia, but rather his recognition of the relationship between power and knowledge. In addition to the perspectives provided by Said's rethinking of the concept of Orientalism, the field of postcolonial theory considers the relationship between 
academic knowledge and the history of colonialism, whether this concerns former colonies, former colonising powers or places that do not neatly fit this schema (Young 2001).

Miyoshi and Harootunian's (2002) collection, Learning places, considered the place of area studies in the early twenty-first century, with a focus on North America. While acknowledging the critiques of the power relations inherent in the 'area studies' model, Gayatri Chakravorty Spivak (2003) has also argued for the importance of the rigorous language training and the deep familiarity with the society and culture that were nurtured in area studies and comparative literature programs.

Australia has a strong tradition of 'area studies', particularly in such places as the former Research School of Pacific and Asian Studies at The Australian National University (Lal and Ley 2006; Macintyre 2010: 58-59). Indeed, the establishment of this school (originally the School of Pacific Studies) was intimately connected with Australia's position as colonial administrator of Papua New Guinea, as noted above (Macintyre 2010: 66). In this sense, Australian social sciences from the beginning had much in common with the colonialist focus of Euro-American social sciences.

Some of the other newer universities included a focus on Asian studies after World War II. Monash University, established in 1961, appointed a historian of Indonesia, John Legge, as its foundation Professor of History. Legge went on to chair the world-renowned Centre for Southeast Asian Studies and also became Dean of Arts. In 1966, Prague School linguist Jiř́ V. Neustupný established a Japanese-language program at Monash based on a communicative modeldifferent to existing 'Oriental studies' programs, which tended to focus on classical literatures rather than the real-world usage of language and the study of contemporary societies. Several other universities established programs in Asian languages and studies in the 1960s, including the University of Queensland, the University of Melbourne, Swinburne, and the West Australian Institute of Technology (now Curtin University). In the 1970s, secondary schools also started to teach some Asian languages.

There has been less reflection on the meaning of this history in the Australian context compared with the above-mentioned debates in the United States, though some contributors to this volume have undertaken critical reflection on 
the construction and role of area studies in Australia. ${ }^{6}$ Australia was also the site for much of the early work by the subaltern studies group, which interrogated the colonial basis of European knowledge about South Asia. Ranajit Guha was based at The Australian National University, and Dipesh Chakrabarty completed his doctoral dissertation there. ${ }^{7}$

One of the purposes of this volume is to engage in a discussion about the intellectual basis of our pursuits, in a dialogue between social scientists from Australia and the region. Ideally, this will encourage a more contemporary model of the social sciences, which is based on a recognition of international connectedness, and also of the diversity of social science traditions from which we can learn. In other words, the Australian social sciences need to continue to move beyond their origins in Euro-American traditions, and beyond the purely pragmatic focus of some forms of area studies, to embrace other sources and forms of knowledge, while still retaining all that is beneficial and useful about those traditions. A further impetus for developing this broader intellectual dialogue comes from the conditions of globalisation and the changing geopolitics of knowledge.

\section{Social sciences and globalisation}

The contemporary world is characterised by changing economic relationships accompanied by the increasingly rapid and intensified circulation of finance, commodities, people, signs and symbols - often called globalisation. Many forms of corporate activity are carried out on a global scale; production and consumption transcend the scale of the nation-state; and institutions of global governance are gradually developing to deal with issues that go beyond the boundaries of one nation-state. ${ }^{8}$ New forms of transnational activism have also developed to deal with these changing relationships. Globalisation has been

\footnotetext{
6 See Jayasuriya (2012); Mackie (2007: 103-20; 2013: 293-301); Morris-Suzuki (2000, 2011); and chapters by Jayasuriya and Morris-Suzuki in this volume; see also Jackson (2015). In the late 1990s, the Australian Research Council, the Academy of the Humanities and the Academy of the Social Sciences surveyed academic disciplines in Australia. There are no specific chapters on Asia or the Pacific in the social science volumes, but there are several chapters on area studies in the humanities volumes (Academy of the Social Sciences in Australia 1998; Aveling 1998: 29-39; Brasted 1998: 239-49; Coaldrake and Wells 1998: 151-63; Denoon and Ward 1998: 209-14; Hooper 1998: 57-66; Ingleson 1998: 251-60; Milner and Morris-Suzuki 1998: 113-27; Saikal 1998: 199-207). For a more recent survey of humanities, arts and social science disciplines, see Turner and Brass (2014; on 'Asia-related' research, see pp. 66-67). In November 2013, the Australian Council of Learned Academies (ACOLA) brought together a group of Australia-based academics to consider 'Science and Research Collaboration with Asia and the Pacific'. For a report on this meeting, see Ang et al. (2015).

7 See Amin and Chakrabarty (1996); Arnold and Hardiman (1994); Bhadra et al. (1999); Chakrabarty (1992: 101-8; 2014: 194-206); Chatterjee and Pandey (1992); and Guha (1982-89).

8 See, inter alia, Grewal and Kaplan (1994); Hannerz (1987: 546-49; 1989: 66-75); Mattelart (1983); Tambiah (2000: 163-94); and Tolentino (1996: 49-76).
} 
described as 'a process of intensifying global social inter-relatedness, whereby space and time are compressed and previously separated locations [are] brought into a new proximity' (Eschle 2002: 316). One of the challenges faced by social scientists is to shift from addressing issues in a largely national frame to addressing issues that necessarily cross national borders. Our focus is on the challenges faced in the Asia-Pacific region, and how social scientists can contribute to the solution of pressing regional problems.

The world is currently undergoing major shifts in economic and social power. These shifts have been explored by writers as diverse as Kishore Mahbubani in The new Asian hemisphere (2008) and Michael Spence in The next convergence (2011). These shifts have particular implications for Australia in its location in the Asia-Pacific region. As we have seen, the former Australian Labor Party government referred to the 'Asian Century' (Commonwealth of Australia 2012), a term that was also used at times by then Prime Minister Abbott (2014). The United States recognised the shifting geopolitics, particularly the rise of China, in 2011 when President Obama stated the policy of a 'pivot to Asia' (Foreign Policy Initiative 2011). ${ }^{9}$

In this volume, we argue that dealing with these shifts involves not just a reorientation of economic and political power but also a changing geopolitics of knowledge. Consequently, in the twenty-first century, it is necessary not just to make the languages and societies of the region objects of study but also to engage with the diverse forms of knowledge produced outside the EuroAmerican centres. It is particularly important to recognise the methodological and theoretical as well as empirical contributions that the diverse forms of knowledge and diverse intellectual traditions in the region can generate. There has been a long history of university academics in Asian countries being encouraged to engage with 'Western' thought (Huang 2007: 422). The original Colombo Plan itself reflected these pressures, as a range of professionals in the region, including academics, was encouraged to study abroad. This pressure has intensified with the internationalisation of university education, and academics are increasingly being encouraged to publish in English in highranking international journals - a development that has led to critiques that more 'local' issues are being neglected in favour of issues that will attract an international readership (Mok 2007: 446) ${ }^{10}$ The exchange has been excessively one-sided: there has not been sufficient reciprocal pressure on academics in Western countries to engage with the knowledge being produced in the

9 There was also criticism that the US government failed to back up its policy on Asia with adequate budget initiatives (Stewart 2013: 1-3).

10 See also the chapters by Patel, Chua and Jayasuriya in this volume. Peter Jackson (2015: 24) has recently argued that the current conditions of transnational academic publishing and research quality auditing regimes entrench Euro-American dominance. 
Asia-Pacific region (even when this knowledge is being produced in English). Here, we argue that a new approach is needed and that we need to develop a far more ambitious idea of what intellectual engagement with the region involves, one that goes beyond the approaches embedded in the early years of the development of the social sciences in Australia. To begin with, we need to go beyond the area studies model of taking 'other countries' as an object of study in order to determine their difference from some abstract Euro-American ideal. Rather, we need to take time to reflect on the intellectual rather than simply instrumental underpinnings of our engagement with the region (Morris-Suzuki 2000: 9-23; 2011: 123-42; and in this volume).

Furthermore, if Australian students are to understand the specificities of Australian society, and of other societies in the region, they need to understand that, for example, the concepts of state and civil society, modernity, and gender and sexuality that are prevalent in Australia are not universal. ${ }^{11}$ They need to be aware of other concepts, of other ways of seeing the world, as well as their implications for other forms of governance and for analysing the policy challenges that Australia faces in the twenty-first century.

This will involve an openness to engaging with the knowledge being produced in many diverse parts of our region, and it will require a consciousness of the political, economic and social issues arising from the increasing integration of Australia's society and economy into the Asia-Pacific region. As Kanishka Jayasuriya (among other contributors to this book) points out, we face many shared problems and issues that are regional in nature, including the political and social challenges of inequality in the region, urbanisation, access to public space and infrastructure, the funding, governance and provision of regional public goods, and transnational environmental challenges.

Furthermore, as the twenty-first century progresses, it will be increasingly difficult for even those Australian academics who focus primarily on domestic economic, social and political analyses to divorce their work from broader regional considerations. Australia is increasingly integrated into the Asia-Pacific region in ways that affect many aspects of Australian domestic policy. For example, the former Labor government noted the impact of the Asian Century-driven resources boom on Australia's 'patchwork economy' (Gillard and Swan 2011) and justified the National Broadband Network proposal partly on the grounds that Australia was falling behind key Asian competitors in internet speeds (Conroy 2007; Singh and Johnson 2013: 129-51).

\footnotetext{
11 On differing concepts of state and civil society, see, for example, Lyons and Gomez (2005); and Wang (2011: xxv-xxviii). On differing concepts of modernity, see, for example, Hobson (2004); and Wang (2011). On differing concepts of gender and sexuality, see Jackson (2001); Mackie (2000; 2007: 103-20); and Mackie and McLelland (2015: 1-17).
} 
Meanwhile, Abbott government Treasurer Joe Hockey (2012) suggested while in Opposition that the Asian Century would require a reduction in Australian government benefits and entitlements, given that Australia would be competing with countries in the region that spend a much smaller percentage of gross domestic product (GDP) on 'public welfare and health care and pension costs'. Engagement with Asia also has implications for Australia's institutional structures, as our state and federal governments try to engage in trade and industry development with Asian competitors and markets where the units of decision-making may be very different. Consider, for example, the key role of city and regional governments in Chinese industry policy, including in areas such as biotechnology and information technology. Engaging with the region will therefore have multiple implications for public policy analyses.

\section{The scope of this book}

The authors of this volume draw on insights from economics, education, gender studies, history, political science, psychology, sociology and urban planning. Issues covered range from the internationalisation of Australian tertiary education to the contributions to be made to understanding shared regional problems such as climate change, reproductive control, trade liberalisation and financial governance by engaging with diverse social science traditions.

As discussed above, this process of reflection impels us to re-examine the history of the social sciences and to consider how Australian academics are positioned as inheritors of Euro-American and Anglophone ways of thinking about the social sciences (Connell 2007). This also means recognising Australia's position as an Anglophone colonial-settler society with a significant Indigenous population, located geographically in the Asia-Pacific region. Indigenous Australians were in communication with the places now known as Indonesia, Timor-Leste and Papua New Guinea well before white settlement. Furthermore, a significant component of our population consists of international students from the Asia-Pacific region (some of whom will become immigrants), other immigrants from the region and the descendants of Asian Australians who immigrated in earlier generations (Jupp 2007; Martin et al. 2015).

A further context for our discussions, as noted above, is the question of how to practise the social sciences in an age of global connectedness in which people, products and images are engaged in constant mobility across national borders. ${ }^{12}$ Many of the issues that engage the social sciences are problems that, by their

12 Donald and Mackie (2009: 1-14); Mackie (2013: 293-301); Mackie and Pendleton (2010); Mackie and Stevens (2009: 257-73). 
very nature, cross national boundaries. These include questions of climate change, environmental disasters like earthquakes and tsunamis, labour mobility and the political economy of inequality, asylum-seeking, and pandemics that spread rapidly across the globe.

The chapters in this volume present the diversity of the social sciences in the region. Our aim is to bring diverse ways of doing social sciences into dialogue with each other; to consider the role of Australia-based social scientists in mediating between different ways of doing social sciences in the region; to provide an intellectual, social scientific framework for calls to engage with the Asia-Pacific region and to develop Asia literacy; and to consider the role of the social sciences in addressing pressing transnational social concerns in the region. A key aim of the volume is to draw the attention of Australian social scientists to some of the exciting insights that can be gained from engaging with the rich and diverse social science traditions in our region.

The book begins with chapters that address broad issues of how contemporary social science was and is constructed and the implications for developing a twenty-first-century social science. Raewyn Connell draws on her previous work in her path-breaking book Southern theory (2007). She acknowledges that the social sciences in Australia were originally influenced by the impact of colonialism on the development of European social sciences with a corresponding neglect of other social science traditions from Africa, South America and Asia. Connell gives examples of major social science work that has been neglected as a result. She draws out some of the implications of this changing geopolitics of knowledge for Australian higher education policy, including the need to develop a research evaluation policy that values broader intellectual traditions.

Sujata Patel argues that the social sciences in the twentieth century inherited a colonial form of knowledge from the nineteenth century that divided them into separate disciplines having distinct national traditions. Some of these national traditions were then privileged over others. Some, particularly those associated with the West, were considered universally applicable forms of knowledge, while others were considered more localised and particular. Patel analyses some of the problems associated with this world view, and argues for a more global social science that incorporates useful insights from a range of national traditions. Such a global social science, she suggests, would be better able to address issues and problems in an increasingly globalised and interconnected world.

Chua Beng-Huat emphasises that it is important for scholars in Asia to accept the West as one particular point of reference among others and to multiply the points of reference to include Asian instances that can also be compared with each other. In the process, the West is no longer privileged as the point of comparison, and Asia and the West can be treated as relative equals. He argues 
that such comparisons of political and economic practices can generate concepts that explain developments in Asia more adequately than the mere application of presumed 'universal' concepts generated outside Asia. For example, one can better understand the differing economic models and strategies pursued in South Korea and Singapore if one contrasts and compares these countries with each other, rather than merely making comparisons with a supposedly universal model. Chua gives additional examples from urban planning, cultural production and democratic institutions.

Kanishka Jayasuriya explores how the concept of the Asian Century problematises key assumptions of both area studies and social sciences. He argues that area studies is based on a view of Asia as 'out there' rather than 'within' the mainstream of academic disciplinary inquiry. Rather than regarding the study of Asia as a special case, such study should be incorporated into all levels of analysis, including the social, political and institutional. Jayasuriya proposes that we also need to draw on the methodological and analytical insights of important work being produced in Asian universities, which provides new insights into common social science problems. Examples he gives include Cui Zhiyuan's (2005) work advocating new forms of economic decentralisation and property rights in China; Neera Chandhoke's (1995) innovative work on Indian civil society and new forms and patterns of representation; and Pasuk Phongpaichit et al.'s (1998) work on Thai society and economy. Through mainstreaming such research and issues, we can develop an interdisciplinary, problem-oriented approach that enables us to build research around key issues, problems and puzzles of social, economic and political transformations pertaining to the region as a whole. Such regional issues range from those of inequality and urbanisation to those of public goods and environmental issues.

Having analysed the ways in which the contemporary social sciences were constructed and arguing for the development of a more flexible, inclusive and global social science that draws on diverse traditions as required, subsequent chapters in the book undertake more specific analyses of case studies in the region, while others engage with the Australia in the Asian Century White Paper.

Sylvia Estrada-Claudio shows how reproductive health issues in the Philippines have involved a process of mediating the claims and perspectives of the national government, the church, medical professionals, non-governmental organisation (NGO) activists, multilateral aid agencies and individuals. Her chapter focuses on the local and international alliances forged between politicians, activists, medical professionals and academics, and the implications for our understanding of citizenship, political activism and social science scholarship in a regional frame. 
Tessa Morris-Suzuki's chapter brings important social science analyses to bear on common ways in which the issue of Asian engagement is imagined, in the process illustrating some of the contributions that such analyses can make to our understanding of key issues in the region. Morris-Suzuki argues that placing the rise of Asia so squarely in an economic framework obscures some important dimensions of regional change and regional interaction. For social scientists and other researchers, it is also important to consider the region through a different prism: that of the end of the Cold War and the creation of a post-Cold War order. Such a prism provides additional insights into the economic rise of Japan, South Korea, Taiwan and other economies, with implications for both foreign and economic policy and for our understanding of key issues in the region.

Leong Liew analyses economic thought in China, noting both similarities and differences in approaches and methods compared with conventional Western economics, including differing views on the nature and role of the state in regard to markets. This has major policy impacts. He argues that such differences need to be grasped if we are to have a thorough understanding of the Chinese economy. The role of the state in the Chinese economy highlights the need to rethink some key aspects of contemporary Western economic thought.

The final group of articles addresses and moves beyond the concept of the Asian Century. Ken Henry - who oversaw the process leading to the White Paper on Australia in the Asian Century - analyses the background of the White Paper. Henry outlines the social, political and economic challenges facing Australia in the twenty-first century, emphasising the need for a compelling narrative and vision of Australia's future. In particular, he argues that we need Australians with the knowledge and skills to develop strong relationships in the region. In order to build partnerships, we need the capacity to understand and operate in cultures, languages and mindsets other than our own. Within Australia we need to ensure that we have the advisory, decision-making and representational structures in place to make informed decisions in an increasingly complex environment. Social scientists in Australia have important contributions to make in developing these skills and capacities and contributing to developing the knowledge necessary for making well-informed policy decisions.

Ariel Heryanto points out that the White Paper on Australia in the Asian Century is the latest in a string of government documents and statements to emphasise 'Asia literacy'. Heryanto explores what is meant by the concept of literacy and the ways in which it can lead to biases when examining and interpreting social practices in modern but oral-oriented societies. Heryanto points out that in Indonesia some of the most valued information and messages are usually shared through face-to-face communication, in which body language is as important as words. He therefore draws attention to the need for Asia literacy knowledge, analyses and policies in Australia to engage with such differences. 
Simon Marginson analyses the changing geopolitics of higher education in the light of the rise of Asian and Southeast Asian universities in the Asian Century. Marginson compares the higher education systems in the United States, Asia and 'Westminster' (the United Kingdom, Australia and New Zealand) in terms of differences in the role and nature of the state, educational cultures, financing of higher education and politico-economic dynamics of research. He then draws out the implications for the Australian social sciences and for Australian education policy.

Just as we wish to introduce readers to the diversity of 'doing' social sciences in the region, so too have we incorporated a diverse range of views and approaches in this book. While all of our contributors welcome the increased attention to Australia's interactions with the Asia-Pacific region, many wish to challenge the instrumentalist focus of much of the existing discussion. As we have seen, Connell, Patel and Chua all recognise the colonial background to Anglophone social sciences (as it has been practised in Australia, too) and argue for a decolonisation of social science methodologies. Several authors are critical of the focus on economics in the discussion of 'engagement with the AsiaPacific region'. Morris-Suzuki argues for a more historically informed approach, which recognises that much of our earlier engagement with the region was informed by a Cold War world view and that we need to come to terms with the post-Cold War order. Heryanto points out the limitations of the Asia literacy model that informs the discussion of Asian studies education. We believe that encouraging such diversity of views and approaches not only contributes to a better understanding of the nature and range of social science knowledge, it also encourages academic discussion and debate on the important issues that this book addresses. Indeed, pursuing differing approaches can help to provide a more complete picture of the complex events and processes that are occurring in the Asia-Pacific region, producing forms of knowledge that can complement rather than contradict each other. In this introduction, we have drawn attention to complex interactions between cultural, political and economic factors that have helped to shape Australian understandings of, and responses to, our region.

\section{Conclusion}

In a radio interview, Kishore Mahbubani, Dean of the Lee Kuan Yew School of Public Policy at the National University of Singapore, has claimed that ' $[\mathrm{b}] \mathrm{oth}$ the Australian population and, what is even more frightening, the Australian intelligentsia at large, is out of touch with the new realities of Asia' (Mahbubani 2012). He argues that Australians have lived in a comfortable Western bubble and that the intelligentsia has 'become complacent'. Consequently, Mahbubani (2012) argued that the Australian education system had failed and that there 
was a need for a 'mental revolution' in Australia and a substantial 'mindset' change. This book is an indicator that Mahbubani has underestimated the determination of Australian academics to engage intellectually with the diverse social science knowledge produced in the Asia-Pacific region. Indeed, we see such an engagement as being part of our role in an intellectual 'intersection' society and that such mediation is an important part of the contribution that Australia-based academics can make to international social science.

This book demonstrates that there are diverse social science traditions from various parts of the world that can usefully be drawn upon. Australian universities are particularly well placed to seize the teaching and research opportunities arising from Australia's geographical location and intellectual history. We can become an intersection university system, drawing on all that is best of the knowledge produced in European and North American universities and all that is best of the diverse forms of knowledge being produced in the great universities of the Asia-Pacific region. In doing so, we will position ourselves well to operate successfully in the international higher education system of the twenty-first century. These shifts in the geopolitics of knowledge make this an exciting time to be a social scientist, facilitating an intellectual engagement between diverse traditions. Indeed, Australian social scientists are arguably already at the forefront of such engagement. This book is intended to be a contribution to an international discussion about how to best practise the social sciences under conditions of globalisation when there is a shifting geopolitics of knowledge.

\section{References}

Abbott, Tony. 2014. Address to the Asia Society. 25 March, Canberra. URL: www.pm.gov.au/media/2014-03-25/address-asia-society-canberra. Consulted 20 October 2014.

Academy of the Social Sciences in Australia. 1998. Challenges for the social sciences and Australia. 3 vols. Canberra: Commonwealth of Australia.

Amin, Shahid and Chakrabarty, Dipesh. eds. 1996. Subaltern studies: Writings on South Asian history. Vol. 9. Delhi: Oxford University Press.

Ang, Ien, Tambiah, Yasmin and Mar, Phillip. 2015. Smart engagement with Asia: Leveraging language, research and culture. Report for the Australian Council of Learned Academies (ACOLA). Canberra: ACOLA.

APEC [Asia-Pacific Economic Cooperation]. n.d. History. URL: www.apec.org/ About-Us/About-APEC/History.aspx. Consulted 15 September 2014. 
Arnold, David and Hardiman, David. eds. 1994. Subaltern studies: Essays in honour of Ranajit Guha. Vol. 8. Delhi: Oxford University Press.

Asian Studies Association of Australia. 2002. Maximising Australia's Asia knowledge: Repositioning and renewal of a national asset. Melbourne: Asian Studies Association of Australia. URL: asaa.asn.au/publications/Reports/ asia-knowledge-book-v70.pdf. Consulted 7 October 2013.

Asian Studies Council. 1988. A national strategy for the study of Asia in Australia. Canberra: Australian Government Publishing Service.

Asian Studies Council. 1989. Asia in Australian higher education: Report of the inquiry into the teaching of Asian studies and languages in higher education. Canberra: Asian Studies Council.

Auchmuty, James J. 1971. The teaching of Asian languages and cultures: Report of the Commonwealth Advisory Committee. Canberra: Commonwealth Government Printing Office.

Australian Education International. n.d. Endeavour Scholarships and Fellowships. URL: aei.gov.au/scholarships-and-fellowships/Pages/default. aspx. Consulted 24 August 2014.

Aveling, Harry. 1998. Asian languages and literatures. In Reference Group for the Australian Academy of the Humanities, ed. Knowing ourselves and others: The humanities in Australia into the 21st century. Vol. 2. Canberra: Commonwealth of Australia.

Bhadra, Gautam, Prakash, Gyan and Tharu, Susie. eds. 1999. Subaltern studies: Writings on South Asian history and society. Vol. 10. Delhi: Oxford University Press.

Bishop, Julie. 2013a. Address to Liberal Friends of India launch. Speeches. URL: www.juliebishop.com.au/speeches/1269-address-to-liberal-friends-of-indialaunch.html. Consulted 6 October 2013.

Bishop, Julie. 2013b. A new vision for engaging in the region. Address to the Australasian Council of Deans of Arts, Social Sciences and Humanities 2012 Conference, The Australian National University, Canberra. Speeches. URL: www.juliebishop.com.au/speeches/1178-a-new-vision-for-engaging-in-theregion.html. Consulted 11 September 2013.

Bishop, Julie. 2013c. Australian foreign policy debate. 7 August 2013, Lowy Institute for International Policy, Sydney. URL: www.lowyinstitute.org/files/ documents/events/australianforeignpolicydebate_transcript_7august2013. pdf. Consulted 6 October 2013. 
Brasted, Howard. 1998. South Asian studies. In Reference Group for the Australian Academy of the Humanities, ed. Knowing ourselves and others: The humanities in Australia into the 21st century. Vol. 2. Canberra: Commonwealth of Australia.

Breckenridge, Carol A. and van de Veer, Peter. 1993. Orientalism and the postcolonial predicament. In Carol A. Breckenridge and Peter van de Veer, eds. Orientalism and the postcolonial predicament: Perspectives on South Asia. Philadelphia: University of Pennsylvania Press.

Chakrabarty, Dipesh. 1992. Trafficking in history and theory: Subaltern studies. In Ken K. Ruthven, ed. Beyond the disciplines: The new humanities. Canberra: Australian Academy of the Humanities.

Chakrabarty, Dipesh. 2014. Communing with magpies. History Australia 11(3): 194-206.

Chandhoke, Neera. 1995. State and civil society: Exploration in political theory. New Delhi: Sage.

Chatterjee, Partha and Pandey, Gyan. eds. 1992. Subaltern studies: Writings on South Asian history and society. Vol. 9. Delhi: Oxford University Press.

Chen, Kuan-Hsing and Huat, Chua Beng. 2002. An introduction. Inter-Asia Cultural Studies 1(1): 9-12.

COAG [Council of Australian Governments]. 1994. Asian languages and Australia's economic future: A report prepared for COAG on a proposed national Asian languages/studies strategy for Australian schools. Canberra: Australian Government Publishing Service.

Coaldrake, William and Wells, Ken. 1998. Japanese and Korean studies. In Reference Group for the Australian Academy of the Humanities, ed. Knowing ourselves and others: The humanities in Australia into the 21st century. Vol. 2. Canberra: Commonwealth of Australia.

Committee of Concerned Asian Scholars. 1968. CCAS Newsletter (1)(May). URL: criticalasianstudies.org/assets/files/bcas/v0ln01.pdf. Consulted 23 September 2014.

Commonwealth of Australia. 2012. Australia in the Asian Century. White Paper. Canberra: Commonwealth of Australia. URL: pandora.nla.gov.au/ pan/133850/20130914-0122/asiancentury.dpmc.gov.au/white-paper.html. Consulted 17 July 2014. 
Connell, Raewyn. 2007. Southern theory: The global dynamics of knowledge in social science. Oxford: Polity.

Conroy, Stephen. 2007. ALP media statement. 25 March. URL: www.alp.org.au/ media/0307/mscom250.php. Consulted 27 March 2007.

Cui, Zhiyuan. 2005. Liberal socialism and the future of China: A petty bourgeoisie manifesto. In Cao Tianyu, ed. China's model for modern development. London: Routledge.

Dale, Leigh. 2012. The enchantment of English: Professing English literatures in Australian universities. Sydney: Sydney University Press.

d'Cruz, J. V. and Steele, William. 2003. Australia's ambivalence towards Asia. Melbourne: Monash Asia Institute/Monash University Press.

Denoon, Donald and Ward, Gerard. 1998. Pacific Islands studies. In Reference Group for the Australian Academy of the Humanities, ed. Knowing ourselves and others: The humanities in Australia into the 21 st century. Vol. 2. Canberra: Commonwealth of Australia.

Department of Defence. 2000. Defence gets new state-of-the-art language school. URL: www.defence.gov.au/minister/2tpl.cfm?CurrentId=269. Consulted 23 September 2014.

DFAT [Department of Foreign Affairs and Trade]. n.d. New Colombo Plan. URL: www.dfat.gov.au/new-colombo-plan/about.html. Consulted 24 August 2014.

Donald, Stephanie Hemelyrk and Mackie, Vera. 2009. Working in the space between. Journal of Multidisciplinary International Studies 6(1)(January): 1-14. URL: epress.lib.uts.edu.au/journals/index.php/portal/article/ view/1220/1236. Consulted: 7 October 2013.

Dower, John. 1975. E. H. Norman, Japan and the uses of history. In John Dower, ed. Origins of the modern Japanese state: Selected writings of E. H. Norman. New York: Pantheon.

Downer, Alexander. 2005. Speech on the launch of 'Australia and the Colombo Plan, 1949-1957'. URL: www.foreignminister.gov.au/speeches/2005/050523_ colombo_plan.html. Consulted 8 March 2015.

Eschle, Catherine. 2002. Engendering global democracy. International Feminist Journal of Politics 4(3): 315-41.

FitzGerald, Stephen. 1980. Asia in Australian education: Report of the Committee on Asian Studies to the Asian Studies Association of Australia. Canberra: Asian Studies Association of Australia. 
Foreign Policy Initiative. 2011. The Obama administration's pivot to Asia: A conversation with Assistant Secretary Kurt Campbell, moderated by Robert Kagan. 13 December. URL: www.foreignpolicyi.org/files/uploads/ images/Asia\%20Pivot.pdf. Consulted October 2013.

Gillard, Julia and Swan, Wayne. 2011. Transcript of joint press conference. 22 August, Canberra. Press Office. Canberra: Department of Prime Minister and Cabinet. URL: www.pm.gov.au/press-office/transcript-joint-pressconference-canberra-14. Consulted 20 September 2012.

Grewal, Inderpal and Kaplan, Caren. eds. 1994. Scattered hegemonies: Postmodernity and transnational feminist practices. Minneapolis: University of Minnesota Press.

Guha, Ranajit. ed. 1982-89. Subaltern studies: Writings on South Asian history. Vols 1-6. Delhi: Oxford University Press.

Hall, C. Michael. 2009. 'A long and still-unfinished story?': Constructing and defining Asian regionalisms. In Tim Winter, P. Teo and T. C. Chang, eds. Asia on tour: Exploring the rise of Asian tourism. London: Routledge.

Hannerz, Ulf. 1987. The world in creolization. Africa 57(4): 546-59.

Hannerz, Ulf. 1989. Notes on the global ecumene. Public Culture 1(2)(Spring 1989): 66-75.

Hobson, John M. 2004. The Eastern origins of Western civilisation. Cambridge: Cambridge University Press.

Hockey, Joe. 2012. Interview. Lateline. 18 April. Sydney: Australian Broadcasting Corporation. URL: www.abc.net.au/lateline/content/2012/s3480665.htm. Consulted 9 May 2012.

Hooper, Beverley. 1998. Chinese studies. In Reference Group for the Australian Academy of the Humanities, ed. Knowing ourselves and others: The humanities in Australia into the 21st century. Vol. 2. Canberra: Commonwealth of Australia.

Huang, Futao. 2007. Internationalization of higher education in the developing and emerging countries: A focus on transnational higher education in Asia. Journal of Studies in International Education (3-4): 421-32.

Indelicato, Maria Elena. 2015. Australia's 'Colombo Plan': The beacon of Western knowledge in the Asia-Pacific region. Critical Race and Whiteness Studies 11(1): 1-16. 
Ingleson, John. 1998. Southeast Asian studies. In Reference Group for the Australian Academy of the Humanities, ed. Knowing ourselves and others: The humanities in Australia into the 21st century. Vol. 2. Canberra: Commonwealth of Australia.

Jackson, Peter A. 2001. Pre-gay, post-queer: Thai perspectives on proliferating gender/sex diversity in Asia. In Gerard Sullivan and Peter A. Jackson, eds. Gay and lesbian Asia: Culture, identity, community. New York: Harrington Park Press.

Jackson, Peter A. 2015. Spatialities of knowledge in the neoliberal world academy: Theory, practice and 21st century legacies of area studies. Bonn: Crossroads Asia Working Series.

Jayasuriya, Kanishka. 2012. A teachable moment. Global Asia 7(2): 88-91.

Johnson, Carol, Ahluwalia, Pal and McCarthy, Greg. 2010. Australia's ambivalent re-imagining of Asia. Australian Journal of Political Science 45(1): 59-79.

Jones, Paul. 2001. Trading in a 'fool's paradise'? White Australia and the trade diversion dispute of 1936. In Paul Jones and Vera Mackie, eds. Relationships: Japan and Australia, 1870s-1950s. Melbourne: History Monographs and RMIT Publishing.

Jupp, James. 2007. From White Australia to Woomera: The story of Australian immigration. 2nd edn. Cambridge: Cambridge University Press.

Kartomi, Margaret. 2013. Growing up in a musical Quaker family. In Susan Blackburn, ed. Growing up in Adelaide in the 1950s. Sydney: GHR Press.

Keating, Paul. 1992. Asia-Australia Institute address. 7 April. In M. Ryan, ed. Advancing Australia: The speeches of Paul Keating, Prime Minister. Sydney: Big Picture Publications.

Kersten, Rikki, Sebastian, Eugene and Williams, Leslie. 1996. Asian Studies in Australia's higher education sector. Sydney: Research Institute for Asia and the Pacific.

Lal, Brij V. and Ley, Allison. 2006. The Coombs book: A house of memories. Canberra: Research School of Pacific and Asian Studies.

Lowe, David. 2014. New Colombo Plan can change how we see Asia: If done right. The Conversation 25 June. URL: theconversation.com/new-colomboplan-can-change-how-we-see-asia-if-done-right-28301. Consulted 24 August 2014. 
Lyons, Lenore T. and Gomez, James. 2005. Moving beyond the OB markers: Rethinking the space of civil society in Singapore. Sojourn: Journal of Social Issues in Southeast Asia 20(2): 119-31.

McFadyen, C. H. 1949. Acting Director of the Division of Industrial Development, column. Exports of Australia February: 27-28.

Macintyre, Stuart. 2010. The poor relation: A history of social sciences in Australia. Melbourne: Melbourne University Press.

Mackie, Vera. 2000. The metropolitan gaze: Travellers, bodies, spaces. Intersections: Gender and Sexuality in Asia and the Pacific 4(September): unpaginated. URL: intersections.anu.edu.au/issue4/vera.html. Consulted 9 October 2013.

Mackie, Vera. 2007. Sexuality in a transnational frame: Australian stories, Japanese stories. In Leigh Dale and Masayo Tada, eds. On the Western edge: Australia and Japan. Perth: Network Books.

Mackie, Vera. 2013. Ways of knowing about human rights in Asia. Asian Studies Review 37(3): 293-301.

Mackie, Vera and McLelland, Mark. 2015. Framing sexuality studies in East Asia. In Mark McLelland and Vera Mackie, eds. Routledge handbook of sexuality studies in East Asia. London: Routledge.

Mackie, Vera and Pendleton, Mark. 2010. On the move: Globalisation and culture in the Asia-Pacific region. Intersections: Gender and Sexuality in Asia and the Pacific 23(January): unpaginated. URL: intersections.anu.edu.au/ issue23/mackie_pendleton.htm. Consulted 7 October 2013.

Mackie, Vera and Stevens, Carolyn S. 2009. Globalisation and body politics. Asian Studies Review 33(3): 257-73.

Mahbubani, Kishore. 2008. The new Asian hemisphere: The irresistible shift of global power to the east. New York: Public Affairs.

Mahbubani, Kishore. 2012. Interview. Radio Australia. 2 November. URL: www. radioaustralia.net.au/international/2012-11-02/asian-century-white-papertimely-and-overdue-mahbubani/1038068. Consulted 4 November 2012.

Martin, Fran, Healy, Chris, Iwabuchi, Koichi, Khoo, Olivia, Maree, Claire, Yi, Keren and Yue, Audrey. 2015. Australia's 'Asian Century': Time, space and public culture. The Asia-Pacific Journal 13(6)(February). URL: www. japanfocus.org/-Audrey-Yue/4268. Consulted 9 March 2015. 
Mattelart, Armand. 1983. Transnationals and the Third World: The struggle for culture. Trans. D. Buxton. South Hadley, Mass.: Bergin \& Garvey Publishers.

Miller, Jane and Nicholls, David. 2014. Jocelyn Hyslop, the little-known story of the founding director of social work at the University of Melbourne. Lilith: A Feminist History Journal 20: 21-33.

Milner, Tony and Morris-Suzuki, Tessa. 1998. The challenge of Asia. In Reference Group for the Australian Academy of the Humanities, ed. Knowing ourselves and others: The humanities in Australia into the 21 st century. Vol. 3. Canberra: Commonwealth of Australia.

Miyoshi, Masao and Harootunian, Harry. eds. 2002. Learning places: The afterlives of area studies. Durham, NC: Duke University Press.

Mok, Ka Ho. 2007. Questing for internationalization of universities in Asia: Critical reflections Asia. Journal of Studies in International Education 11(3-4): 433-54.

Morris-Suzuki, Tessa. 2000. Anti-area studies. Communal/Plural 8(1): 9-23.

Morris-Suzuki, Tessa. 2011. Japan and its region: Changing historical perceptions. Sungkyun Journal of East Asian Studies 11(2): 123-42.

NALSAS [National Asian Languages and Studies in Australian Schools]. 1998. Partnership for change: The NALSAS strategy. Canberra: NALSAS.

Nguyen, Viet Thanh and Hoskins, Janet. 2014. Introduction: Transpacific studies-interventions and intersections. In Janet Hoskins and Nguyen Viet Tanh, eds. Transpacific studies: Framing an emerging field. Honolulu: University of Hawai'i Press.

Oakman, Daniel. 2004. Facing Asia: A history of the Colombo Plan. Canberra: Pandanus Books.

Phongpaichit, Pasuk, Piriyarangsan, Sungsidh and Treerat, Nualnol. 1998. Gangs, gambling, gaming: Thailand's illegal economy and public policy. Bangkok: Silkworm.

Rudd, Kevin. 2008. Address at the launch of Inside Kevin 07 by Christine Jackman. 22 July, Sydney. Prime Minister of Australia Media Hub 2008. URL: www.pm.gov.au/media/Speech/2008/speech_0373.cfm. Consulted 15 April 2009.

Rudd, Kevin. 2009. India-Australia joint declaration on security cooperation. 12 November, New Delhi. URL: www.pm.gov.au/node/6324. Consulted 19 November 2009. 
Said, Edward. 1978. Orientalism. Harmondsworth: Penguin.

Saikal, Amin. 1998. Middle Eastern studies. In Reference Group for the Australian Academy of the Humanities, ed. Knowing ourselves and others: The humanities in Australia into the 21st century. Vol. 2. Canberra: Commonwealth of Australia.

Shimazu, Naoko. 1998. Japan, race and equality: The racial equality proposal of 1919. London: Routledge.

Singh, Amita (with a special Australian contribution by Carol Johnson). 2013. A critical impulse to e-governance in the Asia Pacific. New Delhi: Springer.

Spence, Michael. 2011. The next convergence: The future of economic growth in a multispeed world. New York: Farrar Straus \& Giroux.

Spivak, Gayatri Chakravorty. 2003. Death of a discipline: The Wellek Library lectures on critical theory. New York: Columbia University Press.

Spivak, Gayatri Chakravorty. 2008. Other Asias. Oxford: Blackwell.

Tambiah, Stanley J. 2000. Transnational movements, diaspora and multiple modernities. Daedalus 129(Winter): 163-94.

Tolentino, Rolando B. 1996. Bodies, letters, catalogues: Filipinas in transnational space. Social Text 14(3): 49-76.

Torney-Parlicki, Prue. 2000. Somewhere in Asia: War, journalism and Australia's neighbours. Sydney: UNSW Press.

Turnbull, Malcolm. 2015. Assessing the future of the Asia-Pacific-US/Australia dialogue. 31 January. URL: www.malcolmturnbull.com.au/media/future-ofthe-asia-pacific. Consulted 27 February 2015.

Turner, Graeme and Brass, Kylie. 2014. Mapping the humanities, arts and social sciences in Australia. Canberra: Australian Academy of the Humanities.

Universities Australia. 2014. Key facts and data. 7 July. URL: www. universitiesaustralia.edu.au/australias-universities/key-facts-and-data\#. VCD531aOWlI. Consulted 23 September 2014.

Walker, David. 1999. Anxious nation: Australia and the rise of Asia, 1850-1949. Brisbane: University of Queensland Press.

Walker, David and Sobocinska, Agnieszka. 2012. Introduction: Australia's Asia. In David Walker and Agnieszca Sobocinska, eds. Australia's Asia: From yellow peril to Asian century. Perth: UWA Publishing. 
Wang, Hui. 2007. The politics of imagining Asia: A genealogical analysis. InterAsia Cultural Studies 8(1): 1-33.

Wilson, Rob and Dirlik, Arif. eds. 1995. Asia-Pacific as space of cultural production. Durham, NC: Duke University Press.

Wolfe, Patrick. 1999. Settler colonialism and the transformation of anthropology: The politics and poetics of an ethnographic event. London: Cassell.

Young, Robert. 2001. Postcolonialism: An historical introduction. Oxford: WileyBlackwell. 
This text is taken from The Social Sciences in the Asian Century, edited by Carol Johnson, Vera Mackie and Tessa Morris-Suzuki, published 2015 by ANU Press, The Australian National University, Canberra, Australia. 